\title{
A Study on the Survival of Taenia saginata Eggs on Soil in Denmark
}

\author{
By Bente Ilsøe, Niels Chr. Kyvsgaard, Peter Nansen and Svend Aa. Henriksen
}

Department of Veterinary Microbiology, Royal Veterinary and Agricultural University, and National Veterinary Laboratory, Copenhagen, Denmark.

\begin{abstract}
Ilsee, B., N. C. Kyvsgaard, P. Nansen and S. Aa. Henriksen: A study on the survival of Taenia saginata eggs on soil in Denmark. Acta vet. scand. 1990, 31, 153-158. - The infectivity of Taenia saginata eggs exposed to environmental conditions on a natural soil surface in Denmark was studied by feeding the eggs to susceptible calves, followed by determination of the number of cysts developed. The results indicated that a small proportion of the eggs remained infective for 6 $1 / 2$ months, but not for $91 / 2$ months when deposited in May 1986, and for $51 / 2$ months but not for $81 / 2$ months when desposited in September 1987. Viability of eggs was tested in vitro and compared with infectivity obtained in calves.
\end{abstract}

Cysticercus bovis; egg survival; infectivity; viability; soil surface; climate.

\section{Introduction}

Several factors influence the availability and the infectivity of taeniid eggs in the environment; e.g. natural ageing and the exposure to adverse physical and biological factors (Lawson \& Gemmell 1983). Low to moderate temperatures and high humidity are considered to favour long-term survival of taeniid eggs (Gemmell et al. 1983).

Under laboratory conditions Penfold et al. (1937) demonstrated that a small proportion of a batch of $T$. saginata eggs stored in saline at $2-5^{\circ} \mathrm{C}$ maintained infectivity through 95 days but not through 116 days. The survival of infective eggs of $T$. saginata on pasture has been studied in different parts of the world, as thoroughly reviewed by Gemmell (1978), Wilkens (1981), Bürger (1983), Gemmell et al. (1983) and Lawson \& Gemmell (1983).

In Denmark Jepsen \& Roth (1952) demonstrated that eggs of $T$. saginata remained infective after about 5 1/2 months (159 days) at outdoor exposure in a situation where faeces containing tapeworm segments were deposited on grass in winter (February). Yet the maximum duration of survival of eggs was not demonstrated. Under climatic conditions roughly comparable with those in Denmark, Wilkens (1981) in Braunschweig, Western Germany, demonstrated that $T$. saginata eggs applied onto pasture by wastewater irrigation were infective to tracer calves at least 4 months (119 days) after the application in spring (May). However, neither in this study the maximum survival was determined.

It is well documented that the agricultural use of sewage sludge implies a risk of spreading infective $T$. saginata eggs to cattle (Haugaard 1984, Holt 1985, Nansen \& Henriksen 1986). According to new Danish regulations on the agricultural use of sewage sludge, spreading is allowed only on arable land which over the subsequent 12 months is used for grain or seed crops before it is used for pasture or green-fodder crops (Anon. 1985). 
As part of a survey evaluating the effectiveness of these new Danish regulations in preventing the spreading of bovine cysticercosis (Ilsøe \& Kyvsgaard 1988), attempts were made to determine the maximal survival time of infective $T$. saginata eggs deposited on the soil surface in spring and in autumn in Denmark.

\section{Material and methods \\ Experimental design}

Identical batches of $T$. saginata eggs were deposited in small bags on the soil surface. On day 0 and subsequently at intervals of 3 months the infectivity was assessed by inoculating young calves, serologically negative with regard to $C$. bovis, followed by determination of the number of cysts developed in them. Two experiments were carried out. One started in May 1986, the other one in September 1987. The experiments were terminated when inoculation of calves no more led to development of cysts.

\section{Parasite material}

$T$. saginata eggs were obtained from freshly voided segments. In the first experiment, all eggs used were isolated from spontaneously voided segments. In the second experiment, the majority of eggs were obtained from the posterior segments of a tapeworm expelled after treatment with niclosamide. The eggs were suspended in $0.9 \%$ saline and allocated in portions of 11,500 eggs $( \pm 500)$. Only eggs that appeared morphologically fully developed were included in the counting. After mixing with 2-3 grams of a structural material (Vermiculite), the eggs were wrapped in small bags nade of nylon mesh (Monodur $^{\mathbb{B}}$, pore size $22.4 \mu \mathrm{m}$ ). The bags were sealed by melting with hot iron, and their impermeability for eggs was finally tested. The egg bags were then deposited on the soil surface on a site with half-shade.

\section{Infectivity tests}

At intervals of 3 months, 3 egg bags were removed from the soil site. The bags were cut in small pieces, and mesh plus contents were suspended in water and dosed orally to 3 young calves from farms with no history of bovine cysticercosis. Prior to the experiment, these calves were found to be serologically negative with regard to $C$.bovis (Kyvsgaard et al. in press).

The calves were slaughtered 10 weeks post infection. The number of cysts detected by careful slicing into $5 \mathrm{~mm}$ pieces of the heart, liver, kidneys, oesophagus, lungs, spleen, masseters, diaphragm and tongue was recorded. The number of cysts in the forelimbs, hindlimbs and truncus muscles was calculated by doubling the number detected by likewise slicing of the musculature of the left or right half of the carcass. If no cysts were found by this procedure, the remaining musculature was sliced as well. When no cysticerci could be demonstrated in any of the 3 calves in a group, dosing of new calves was discontinued.

\section{Viability tests}

In the second experiment, supplementary : vitro viability testing was carried out on eggs from the batch for the in vivo infectivity tests. Portions of 16,000 eggs were kept in test tubes with saline next to the egg bags. This procedure was used, as observations indicated that the admixture of structural material incriminated the viability testing procedure.

The viability analysis comprised a hatching procedure in sodium hypochlorite followed by an activation test in trypsine/bicarbonate/bile (modified after Stevenson (1983)), as described by Ilsøe \& Kyvsgaard (1988) and Brødsgaard (1989). 
Table 1. Numbers of Cysticercus bovis in calves dosed with eggs of Taenia saginata exposed on the soil for different periods.

PART I:

\begin{tabular}{lrc}
\hline $\begin{array}{l}\text { Duration of } \\
\text { exposure: }\end{array}$ & $\begin{array}{c}\text { No. of cysts } \\
\text { detected: }\end{array}$ & $\begin{array}{c}\text { Mean } \\
\text { (\% of day 0) }\end{array}$ \\
\hline 0 & 1683 & 1144 \\
& 1061 & $(100 \%)$ \\
\hline 3 months & 588 & \\
(13 weeks) & 596 & $\begin{array}{c}439 \\
\text { May-July }\end{array}$ \\
\hline 6 1/2 months & 240 & $(38.4 \%)$ \\
(29 weeks) & 26 & \\
May-November & 22 & 17 \\
\hline $91 / 2$ months & 2 & $(1.4 \%)$ \\
(43 weeks) & 0 & \\
May-February & 0 & 0 \\
\hline
\end{tabular}

PART II:

\begin{tabular}{lrccc}
\hline $\begin{array}{l}\text { Duration of } \\
\text { exposure: }\end{array}$ & $\begin{array}{c}\text { No. of cysts } \\
\text { detected: }\end{array}$ & $\begin{array}{c}\text { Mean } \\
(\% \text { of day } 0)\end{array}$ & $\begin{array}{c}\text { \% infective } \\
\text { of 11,500: }\end{array}$ & $\begin{array}{c}\% \text { viable } \\
\text { of 16,000: }\end{array}$ \\
\hline 0 & $\begin{array}{r}55 \\
154\end{array}$ & $\begin{array}{c}141 \\
(100 \%)\end{array}$ & $1.2 \%$ & $1.7 \%$ \\
\hline $\begin{array}{l}3 \text { months } \\
\text { (12 weeks) }\end{array}$ & 43 & & & \\
Sept.-Dec. & 74 & 94 & & \\
\hline $\begin{array}{l}51 / 2 \text { months } \\
\text { (24 weeks) }\end{array}$ & 164 & $(66.7 \%)$ & $0.8 \%$ & $0.6 \%$ \\
Sept.-March & 66 & & & \\
\hline $81 / 2$ months & 52 & 45 & & 0 \\
(36 weeks) & 16 & $(31.9 \%)$ & $0.4 \%$ & 0 \\
Sept.-May & 0 & & & \\
\hline
\end{tabular}

\section{Results}

The number of cysts developed in the experimentally infected calves in relation to the duration of exposure of the eggs is shown in Table 1 and Fig. 1. The ratio of live to degenerated cysts did not decline with increasing egg age.

The infectivity on day 0 , when measured as the mean number of cysts developed from the 2 egg batches used in each part of the experiment, differed markedly.
In the first experiment, the shape of the dieoff curve of eggs, as drawn between the mean numbers of cysts, was neither linear nor exponential (Fig. 1). A minor number (mean 17) of these eggs remained infective after 29 weeks of exposure (May-November). However, no eggs were found to be infective after 43 weeks (May-February). This experiment included a summer period with temperature up to $30^{\circ} \mathrm{C}$ and no rainfall for 


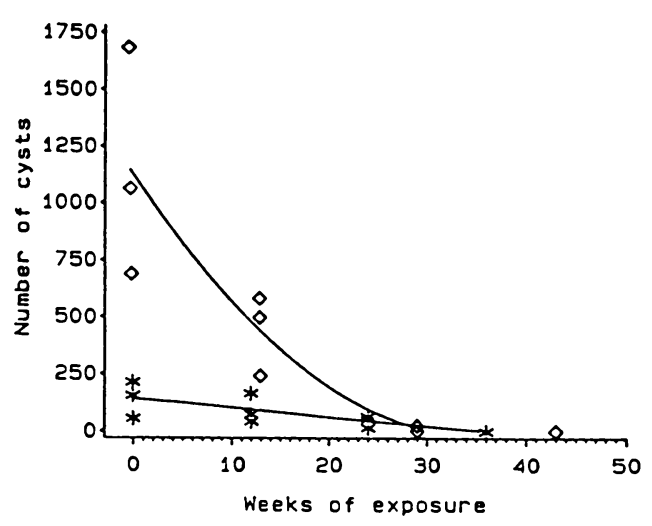

Figure 1. Numbers of $C$. bovis in calves dosed with eggs of $T$. saginata in relation to duration of exposure on the soil:

○): Calves dosed with eggs deposited on the soil in May 1986.

*): Calves dosed with eggs deposited on the soil in September 1987.

Note: The marks at 36 weeks $\left({ }^{*}\right)$ and 43 weeks $(\diamond)$ each represents three calves all found not to harbour cysts.

several weeks, followed by a winter period with average $(24 \mathrm{~h})$ temperatures below zero in January and February, where the temperature occasionally reached $-18^{\circ} \mathrm{C}$.

In the second experiment, the die-off curve of eggs approximated that of a linear function (Fig. 1). A number (mean 45) of eggs remained infective for 24 weeks (SeptemberMarch), but none were found to be infective after 36 weeks (September-May). This experiment was carried out during a winter which was unusually mild for Danish conditions, with average $(24 \mathrm{~h})$ temperatures above zero except for one week in January, where the temperature occasionally reached $-10^{\circ} \mathrm{C}$.

In the second experiment, the percentage of eggs in saline recorded as viable by the hatching and activation tests was roughly in accordance with the percentage of eggs found to be infective from the bags, except for the eggs exposed for 24 weeks. None of the eggs kept in saline through that period were able to hatch and activate, although the infectivity to calves still turned out to be relatively high (Table 1 ).

\section{Discussion}

The main purpose of the described experiments was to define the rate of decline of infectivity and the maximal duration for $T$. saginata eggs remaining infective under conditions prevailing at the surface of $\mathrm{Da}$ nish soil.

The egg portions used in the second experiment showed a markedly lower infectivity on day 0 as compared with the eggs used in the first experiment. This may possibly be ascribed to strain differences between individual T. saginata worms (Froyd 1962, Wouters et al. 1987). The fact that the majority of the eggs of the second experiment originated from segments expelled after anthelmintic treatment may not be decisive, since Gemmell et al. (1983) states that cestocides have no ovicidal effect. However, it seems likely that the batch of eggs may have contained a certain proportion of juvenile eggs, which, even though they appeared morphologically fully developed, were not yet infective on day 0 . Such eggs may reach maturity during the exposure on the soil (Gemmell 1978, Lawson \& Gemmell 1983), thus explaining the slower decline in infectivity of this batch of eggs, as compared to the eggs included in the first experiment (Fig. 1).

The shapes of the die-off curves are likely to be influenced by a multitude of determinants. Apart from genetic and age-related factors, the climatic conditions will also influence the rate of decline of the infectivity, and thereby perhaps explain some of the differences in the shape of the curves from the two experiments. However, the exact die-off pattern of $T$. saginata eggs will demand further studies of the infectivity decline under 
controlled conditions. One should be well aware that such studies are extremely resource requiring.

In previous reports no clear correlation between the viability and the infectivity of Taenia eggs has been recorded (Gemmell 1978, Hughes et al. 1985, Pike 1988). In the present experiment, some accordance between the demonstrated viability and infectivity of eggs seems to have been demonstrated, at least in the initial stages of the trial. However, at the last date (24 weeks exposure), when a small proportion of eggs still were infective, they did not show any viability by the in vitro test. These results therefore suggest that the in vitro viability testing cannot substitute the in vivo infectivity testing. The in vitro viability testing may, however, be useful when estimating the size of the egg doses in an infectivity trial.

In conclusion, the present studies have demonstrated that the survival of infective eggs of $T$. saginata exposed to the climatic conditions prevailing at the soil surface in Denmark, may exceed some $61 / 2$ months from spring to winter and some $51 / 2$ months from autumn to spring, but not $91 / 2$ and 8 $1 / 2$ months respectively. Thus, under practical conditions the legislatory resting interval of 1 year between sludge application and the use of the area for pasture or harvest of fodder crops seems to be sufficient to prevent infection with bovine cysticercosis from $T$. saginata eggs from sludge applied onto farmland.

In a WHO report on the prevention and control of cysticercosis, it is recommended to wait at least 6 months after sludge application before using the area for pasture. However, it is indicated that it cannot be ruled out that cattle may become infected with cysticercosis on sludge treated pasture even after this time, especially if it covers a winter period (Gemmell et al. 1983). Actually, the present results suggest that the resting period recommended by WHO is too short, at least under Danish, and possibly also under other Northern European conditions.

\section{Acknowledgements}

The authors wish to thank chief laboratory technician Grethe Gomme and Dr. Svend Fogh for supplies of $T$. saginata eggs, laboratory technicians Lykke Kieler and Margrethe Pearman, agricultural technician Niels Midtgaard and Mr. John Pedersen and Mr. Henrik Haastrup for valuable practical assistance, Dr. Leslie Harrison, Edinburgh, is thanked for guidance with the implementation of the serological tests, and cand. scient. Camilla Brødsgaard for assistance with the viability tests.

This work was part of a project supported by the Ministry of Agriculture, the Ministry of the Environment and the National Association of Local Authorities.

\section{References}

Anonymous: Bekendtgørelse nr. 574 af 14. november 1984 - om anvendelse af slam i landbruget. (Notice no. 574 of 14th November 1984 on agricultural application of sludge). Danish Environmental Agency 1984, 3 pp.

Brødsgaard $C$ : Humoral og cellulær immunitet mod larvestadierne af Taenia saginata. Biologispeciale ved Københavns Universitet. (Humoral and cellular immunity against the larval stages of Taenia saginata, University of Copenhagen). $1989,189 \mathrm{pp}$.

Bürger HJ: Survival of Taenia saginata eggs in sewage and on pasture. Proceedings of the Third International Symposium on "Processing and use of sewage sludge", Brighton, 27-30 September 1983, 1984, pp. 155-165.

Froyd G: Longevity of Taenia saginata Eggs. J. Parasitol. 1962, 48, 279.

Gemmell MA: The effect of weather on tapeworm eggs and its epidemiological implications. In: Weather and Parasitic Animal Diseases. T. Gibson ed., World Meteorological Org. Techn. Note No. 497, 1978, 159, 83-94. 
Gemmell MA, Matyas Z, Pawlowski Z, Soulsby EJL: Guidelines for Surveillance, Prevention and Control of Taeniasis/Cysticercosis. World Health Organization Geneva, Switzerland VPH/83/49, 1983, $207 \mathrm{pp}$.

Haugaard P: Cysticercosis and salmonellosis in cattle caused by sewage sludge on Danish farmland. Waste Manag. and Res. 1984, 2, 163-168.

Holt K: Taenia sagirata in the Scottish Environment. State Vet. J. 1985, 39, 14-21.

Hughes DL, Norrington IJ, Morris DL, Waite $W M$ : The effect of pasteurisation and stabilisation of sludge on Taenia saginata eggs. In: Inactivation of Microorganisms in Sewage Sludge by Stabilisation Processes. (Strauch, Havelaar and L'Hermite eds.). Proc. CEC seminar, Hohenheim Oct. 1984. Elsevier, 1985, 126-134.

Ilsøe $B$, Kyvsgaard NC: Rapport om overvågningsprojekt vedr. anvendelse af slam i landbruget. (Report of a Surveillance Project on the Agricultural Use of Sewage Sludge). National Veterinary Laboratory and the Royal Veterinary and Agricultural University, Copenhagen $1988,157 \mathrm{pp}$.

Jepsen Aa, Roth H: Epizootiology of Cysticercus bovis - Resistance of the Eggs of Taenia saginata. Proc. of the 14th Int. Veterinary Congress, London. Section 1(b), 1952, 11, 43-50.

Kyvsgaard NC, Ilsøe B, Henriksen SAa, Feld NC, Nansen $P$ : Evaluation of an enzyme-linked immunosorbent assay (ELISA) for detection of Taenia saginata cystercosis in cattle. Acta vet. scand. in press.

Lawson JR, Gemmell MA: Hydatidosis and Cysticercosis: The dynamics of transmission. Adv. Parasitol., 1983, 22, 261-308.

Nansen P, Henriksen SvAa: The epidemiology of bovine cysticercosis $(C$. bovis) in relation to sewage and sludge application on farmland. In: Epidemiological Studies of Risks Associated with the Agricultural Use of Sewage Sludge: Knowledge and Needs (Block, Havelaar and
L'Hermite eds.). Proc. of a CEC seminar, Metz, May 1985. Elsevier 1986, 76-82.

Penfold WJ, Penfold HB, Phillips $M$ : The criteria of life and viability of mature Taenia saginata ova. Med. J. Austr. 1937, Vol. II, 1-5.

Pike EB: Infectivity of Taenia Eggs after Sludge Treatment. Water Research Center Environment Report PRD 1199-M/2-B (ME9147 SLD) England. 1988, $33 \mathrm{p}$.

Stevenson P: Observations on the hatching and activation of fresh Taenia saginata eggs. Ann. Trop. Med. Parasitology 1983, 77, 399-404.

Wilkens $S$ : Untersuchungen über die Ansteckungsmöglichkeiten von Rindern mit Taenia saginata und Sarcocystis spp. auf Abwasserverregnungsflächen und über das Absetzverhalten von Helmintheneiern in vitro. (Investigations on the risk of infection of cattle by Taenia saginata and Sarcocysts spp. by irrigated sewage plant efficient and in vitro trials on the rate of sedimentation of helminth eggs). Inauguraldissertation, Tierärzlichen Hochschule Hannover. 1981, pp 122.

Wouters G, Brandt J, Geerts S: Observations on possible strain differences in Taenia saginata. In: Helminth Zoonoses - Proc. of an Int. colloquium held at the Inst. of Tropical Medicine, Antwerpen 11-12/12 1986, Martinus Nijhoff Publ. 1987, 76-80.

\section{Sammendrag}

En undersogelse af Taenia saginata ag's overlevelsesevne på jordoverfladen i Danmark. $T$. saginata æg, der havde været udsat for miljøforholdene på jordoverfladen i forskellige tidsintervaller, blev infektivitetstestet ved at indgive æggene oralt i modtagelige kalve. Efter slagtning blev antallet af udviklede cysticercer i hver kalv opgjort. Resultaterne viste, at en lille del af æggene havde bevaret infektiviteten i $61 / 2$ måned men ikke i 9 $1 / 2$ måned, når de blev udlagt i maj, og i $51 / 2$ måned men ikke i $81 / 2$ måned, når de blev udlagt $\mathrm{i}$ september. Desuden blev æggenes viabilitet, undersøgt in vitro, sammenlignet med infektiviteten.

(Received June 2, 1989; accepted August 9, 1989).

Reprints may be requested from: Bente Ilsøe, Dept. of Veterinary Microbiology, Royal Veterinary and Agricultural University, Bülowsvej 13, DK-1870 Frb. C, Denmark. 